AGRITECH, Vol. 37, No. 4, November 2017, Hal. 377-385

DOI: http://doi.org/10.22146/agritech.10698

ISSN 0216-0455 (Print), ISSN 2527-3825 (Online)

Tersedia online di https://jurnal.ugm.ac.id/agritech

\title{
Fermentasi Whey Keju Menggunakan Biji Kefir (Kefir Grains) dengan Variasi Sumber Nitrogen
}

\author{
Fermentation of Cheese Whey using Kefir Grains with Variation of Nitrogen Sources
}

\author{
Rohula Utami*, Edhi Nurhartadi, Asri Nursiwi, Maria Angela Martina Andriani, Irina Fitriyaningsih \\ Program Studi Ilmu dan Teknologi Pangan, Fakultas Pertanian, Universitas Sebelas Maret \\ Jl. Ir. Sutami 36 A, Kentingan, Surakarta 57126 \\ Email: rohulautami@staff.uns.ac.id
}

Submisi: 27 April 2016; Penerimaan: 28 Juli 2017

\begin{abstract}
ABSTRAK
Whey keju adalah produk sampingan dari industri pengolahan keju yang masih memiliki kandungan laktosa sebesar 4-5\% sehingga dapat dimanfaatkan sebagai sumber karbon pada media fermentasi oleh biji kefir. Selama proses fermentasi menggunakan biji kefir terjadi pembentukan alkohol, asam laktat dan eksopolisakarida (kefiran). Sumber nitrogen juga dapat mempengaruhi proses fermentasi. Oleh karena itu, dalam penelitian ini dilakukan variasi perlakuan, yaitu variasi konsentrasi laktosa pada whey dan variasi komposisi sumber nitrogen (yeast extract, urea dan ekstrak tauge kacang hijau) sebagai media fermentasi oleh biji kefir. Setelah fermentasi biji kefir selama 24 jam, jumlah biomassa biji kefir berkisar antara 21,30-27,15 g (berat kering g/250 mL medium fermentasi) dari jumlah biomassa awal $25 \mathrm{~g}$. Cairan fermentasi menunjukkan nilai pH berkisar antara 3,49-3,94; kadar alkohol berkisar antara 0,11-0,31\% dan kadar asam laktat berkisar antara $0,49-1,47 \%$. Total rendemen kefiran yang didapatkan dari ekstraksi biji kefir dan cairan fermentasi berkisar antara $0,63-1,76 \mathrm{~g} / \mathrm{L}$. Hasil penelitian ini mengindikasikan bahwa whey keju dengan penambahan sumber nitrogen dapat digunakan sebagai medium fermentasi oleh biji kefir untuk menghasilkan metabolit berupa alkohol, asam laktat dan kefiran. Variasi formulasi media fermentasi yang menghasilkan kefiran dalam jumlah tertinggi adalah penggunaan konsentrasi laktosa whey keju 1,2\% dan sumber nitrogen dari ekstrak tauge kacang hijau sebesar 4\%.
\end{abstract}

Kata kunci: Whey keju; eksopolisakarida; kefiran; biji kefir; sumber nitrogen

\begin{abstract}
Cheese whey is a waste product in cheese processing which contains $4-5 \%$ of lactose. Having high carbon source, this material could be a potential fermentation medium for kefir grains. During fermentation of kefir grains, alcohol, lactic acid and exopolysaccharide (kefiran) were produced. The kefir grains fermentation also affected by nitrogen source. Therefore, effects of different composition of lactose and nitrogen sources (including yeast extract, urea and mung bean sprouts extract) in the fermentation were examined in this study. The results showed that after 24 hours of incubation, kefir grains biomass reached 21.30-27.15 g (dry wt, g/250mL medium) from $25 \mathrm{~g}$ of intial kefir grains biomass. Fermentation broth showed $\mathrm{pH}$ values ranged from 3.49-3.94; alcohol level ranged from 0.11-0.31\%; and lactic acid content ranged from $0.49-1.47 \%$. The total of kefiran extracted from kefir grain and fermentation broth ranged from $0.63-1.76 \mathrm{~g} / \mathrm{L}$. This study indicated that cheese whey can be used as fermentation medium to produce alcohol, lactic acid and kefiran by kefir grains. The highest production of kefiran was achieved in the medium containing $1.2 \%$ of whey lactose and $4 \%$ of mung bean sprouts extract.
\end{abstract}

Keywords: Cheese whey; exopolysaccharide; kefiran; kefir grains; nitrogen source 


\section{PENDAHULUAN}

Biji kefir (kefir grain) adalah campuran starter alami yang mengandung macam-macam bakteri asam laktat dan khamir. Populasi mikrobia yang ditemukan dalam biji kefir merupakan susunan dari komunitas sinbiotik (Otsoa dkk., 2006). Biji kefir berbentuk granula yang tidak beraturan dengan ukuran diameter yang berbeda-beda dari 3-35 mm (Guzel-Seydim dkk., 2005), berwarna putih sampai putih kekuningan serta mempunyai tekstur kenyal dan berlendir (Farnworth, 2005). Biji kefir merupakan kluster dari mikroorganisme yang tergabung oleh suatu matriks protein dan polisakarida (Bottazzi dkk., 1994; Abraham dan De Antoni, 1999). Biji kefir biasanya digunakan sebagai starter alami dalam pembuatan minuman kefir.

Sejumlah penelitian juga melaporkan potensi penggunaan biji kefir dalam proses fermentasi yang lain. Biji kefir dapat digunakan sebagai starter kultur dalam pembuatan roti (Harta dkk., 2004; Plessas dkk., 2005) dan keju (Kourkoutas dkk., 2006; Dimitrellou dkk., 2007; Dimitrellou dkk., 2009; Katechaki dkk., 2008; Katechaki dkk., 2009; Koutinas dkk., 2009). Biomassa biji kefir juga dapat menjadi sumber protein sel tunggal (Paraskevopoulou dkk., 2003; Koutinas dkk., 2005). Metabolit fermentasi seperti etanol (Athanasiadis dkk., 2002; Koutinas dkk., 2007), dan polisakarida (Rimada dan Abraham, 2001; Rimada dan Abraham, 2003; Rimada dan Abraham, 2006) juga dapat dihasilkan dari proses fermentasi menggunakan biji kefir. Polisakarida yang diproduksi oleh mikroorganisme dalam biji kefir disebut dengan kefiran.

Kefiran merupakan produk eksopolisakarida oleh mikroorganisme pada biji kefir yang larut dalam air, atau heteropolisakarida yang mengandung glukosa dan galaktosa (Kooiman, 1968). Kefiran dapat digunakan sebagai pengental, stabilizer, emulsifier, substitusi lemak, gelling agent (Toba dkk., 1986). Kefiran juga memiliki aktivitas antitumor, aktivitas antimikrobial, dan efek positif pada metabolisme kolesterol (Shiomi dkk., 1982).

Mikroba pada biji kefir mampu menggunakan laktosa pada media fermentasi. Menurut Obruca dkk. (2009), limbah whey keju dapat digunakan sebagai sumber karbon dalam media fermentasi kefiran. Hal ini karena limbah whey keju masih mengandung laktosa yang cukup tinggi, yaitu 5-6\%. Dengan demikian, pemanfaatan whey keju sebagai bahan untuk media fermentasi juga dapat mengurangi limbah dari produksi keju yang merupakan masalah polusi bagi lingkungan karena dapat menurunkan kadar oksigen terlarut dalam air.

Beberapa penelitian produksi kefiran sebelumnya menggunakan yeast extract sebagai sumber nitrogen untuk menunjang pertumbuhan bakteri asam laktat agar memiliki masa hidup yang lebih panjang. Cheirsilp dan Sirilaor (2011) melaporkan bahwa perlakuan sampel menggunakan laktosa dari whey dengan penambahan yeast extract menghasilkan rendemen kefiran yang lebih tinggi dibandingkan dengan perlakuan sampel dengan penambahan tryptone dan meat extract. Selain itu pada penelitian Razack dkk. (2013), sampel menggunakan molasse sebagai sumber karbon dengan penambahan yeast extract juga menghasilkan rendemen kefiran optimum yaitu sebesar 1,38 g/L dibandingkan dengan sumber nitrogen lain seperti peptone, $\mathrm{NH}_{4} \mathrm{Cl}$ dan $\mathrm{NaNO}_{3}$. Kandungan N (nitrogen) dalam yeast extract (Merck) sebesar $10,5 \%(\mathrm{db})$. Namun, yeast extract tergolong sumber nitrogen yang mahal.

Sumber nitrogen lain yang dapat ditambahkan kedalam media fermentasi adalah urea dan ekstrak tauge kacang hijau. Urea $\left(\mathrm{CO}\left(\mathrm{NH}_{2}\right)_{2}\right)$ memiliki kandungan nitrogen yang tinggi mencapai 46\% (Amanatin dan Nurhidayati, 2013). Sedangkan tauge kacang hijau merupakan salah satu dari jenis sayuran yang biasa dikonsumsi, murah, mudah didapatkan, dan tidak menghasilkan senyawa yang berbahaya. Tauge kacang hijau mengandung komponen gizi makro dan mikro, vitamin, asam amino, dan gula yang dibutuhkan bagi pertumbuhan mikroorganisme (Richmond, 1986). Dalam 100 g tauge kacang hijau terkandung protein sebesar 3,04\% (USDA, 2016). Ekstrak tauge kacang hijau telah digunakan sebagai medium tumbuh pada kultivasi Spirullina spp, sebagai media tumbuh penyuplai sumber nitrogen pada pertumbuhan kultur probiotik, dan sebagai media pembuatan nata de cane (Hefdiyah dkk., 2013; Dewi, 2014; Arifiani dkk., 2015). Namun, urea dan ekstrak tauge kacang hijau belum pernah dilaporkan digunakan sebagai sumber nitrogen dalam fermentasi whey keju oleh biji kefir. Oleh karena itu, dalam penelitian ini dilakukan variasi perlakuan, yaitu variasi konsentrasi laktosa pada whey dan variasi komposisi sumber nitrogen sebagai media fermentasi oleh biji kefir.

\section{METODE PENELITIAN}

\section{Bahan}

Bahan whey keju diperoleh dari pabrik keju Indrakila Boyolali. Biji kefir didapatkan dari Rumah Kefir Yogyakarta. Sumber nitrogen yang digunakan yaitu yeast extract (Merck), urea (Merck), dan tauge kacang hijau yang didapatkan dari pasar Ledoksari Surakarta (Jawa Tengah). Bahan kimia yang dipergunakan antara lain alkohol 96\%, $\mathrm{NaOH} \mathrm{0,01} \mathrm{N,}$ laktosa standar, Nelson A dan B, arsenomolibdat, indikator phenolphthalein dan aquadest.

\section{Pengembangbiakan Biji Kefir}

Pengembangbiakan dan aktivasi biji kefir mengacu pada metode penelitian Wiithuhn dkk. (2004). Proses yang 
dilakukan meliputi penambahan $500 \mathrm{~mL}$ susu pasteurisasi ke dalam wadah yang telah berisi $100 \mathrm{~g}$ biji kefir. Sampel diinkubasi selama 24 jam pada suhu ruang $25{ }^{\circ} \mathrm{C} \pm 3{ }^{\circ} \mathrm{C}$. Penggantian susu pasteurisasi dilakukan tiap 24 jam hingga biji kefir akan digunakan.

\section{Pembuatan Ekstrak Tauge Kacang Hijau}

Metode yang digunakan dalam pembuatan ekstrak tauge kacang hijau berdasarkan penelitian yang dilakukan oleh Prihantini dkk. (2007) dengan dimodifikasi. Tauge dicuci hingga bersih, dan ditiriskan. Setelah tauge tiris, dilakukan pengecilan ukuran menggunakan blender, dan direbus dengan aquadest mendidih dengan perbandingan 1:5 selama 30 menit. Penyaringan dilakukan untuk memisahkan antara ampas dan ekstrak tauge. Setelah didapatkan ekstrak tauge kacang hijau dilakukan pengukuran densitas menggunakan hidrometer. Setelah densitas diketahui, dihitung volume ekstrak tauge kacang hijau yang ditambahkan untuk konsentrasi 2\% (b/v), dan $4 \%(\mathrm{~b} / \mathrm{v})$.

\section{Fermentasi Biji Kefir pada Media Limbah Whey Keju}

Fermentasi biji kefir dilakukan menggunakan berbagai komposisi media yang berbeda dengan variasi konsentrasi laktosa whey keju dan variasi sumber nitrogen. Whey keju yang digunakan dalam penelitian ini mengandung 5,4\% laktosa. Pengujian kadar laktosa menggunakan metode Nelson-Somogyi (AOAC, 1995). Whey keju diencerkan menggunakan aquades sehingga didapatkan variasi konsentrasi laktosa whey keju (LW) sebesar 1,2\%; 2,4\%; $3,6 \%(\mathrm{v} / \mathrm{v})$. Variasi konsentasi sumber nitrogen terdiri dari YE4\% (yeast extract 4\%), YE2\%U2\% (yeast extract 2\%; urea 2\%), U4\% (urea 4\%), YE2\%ET2\% (yeast extract 2\%; ekstrak tauge kacang hijau 2\%), ET4\% (ekstrak tauge kacang hijau 4\%). Biji kefir sebanyak 25 g dimasukkan ke dalam $250 \mathrm{ml}$ media fermentasi (Magalhães dkk., 2010). Sampel diinkubasi pada suhu $37{ }^{\circ} \mathrm{C}$ selama 24 jam tanpa adanya agitasi (pengadukan).

\section{Analisa Biomassa Biji Kefir dan Media Setelah Fermentasi}

Setelah proses fermentasi, dilakukan pemisahan antara biji kefir dengan media fermentasi menggunakan kertas saring. Pengukuran biomassa biji kefir dianalisis melalui penimbangan dengan metode skala analitis (Rimada dan Abraham, 2001). Sampel media fermentasi yang telah dipisahkan dari biji kefir dilakukan analisis kadar etanol dengan menggunakan hand refractometer alcohol (RHW25 ATC), analisis kadar asam laktat yang mengikuti metode titrimetri dengan $\mathrm{NaOH} 0,01 \mathrm{~N}$ dan analisis $\mathrm{pH}$ menggunakan $\mathrm{pH}$ meter (Oakton PCS-Testr 35).

\section{Ekstraksi Kefiran dari Media Fermentasi dan Biji Kefir}

Ekstraksi kefiran dibagi menjadi dua, yaitu ekstraksi kefiran dari media fermentasi dan ekstraksi kefiran dari biji kefir. Media fermentasi yang telah dipisahkan dari biji kefir dilakukan pemanasan pada suhu $100{ }^{\circ} \mathrm{C}$ selama 15 menit. Sedangkan untuk ekstraksi kefiran dari biji kefir, biji kefir yang telah disaring ditambahkan aquadest dengan perbandingan $1: 10$, w/v, dan dipanaskan selama 15 menit pada suhu $100^{\circ} \mathrm{C}$. Selanjutnya keduanya dilakukan pemisahan sel dan kefiran dalam supernatan dengan sentrifugasi dingin $\left(4^{\circ} \mathrm{C}\right)$ dengan kecepatan 10.000 rpm (Hettich Mikro 22 R) selama 10 menit. Supernatan ditambahkan etanol $96 \%$ dan disimpan pada suhu refrigerator selama 24 jam sebelum dilakukan sentrifugasi (Hettich Mikro $22 \mathrm{R}$ ) kembali pada kecepatan $3.000 \mathrm{rpm}$, suhu $4{ }^{\circ} \mathrm{C}$ selama 30 menit. Dilakukan kembali perlakuan tahap penambahan etanol $96 \%$ dan sentrifugasi. Volume etanol yang ditambahkan dalam tahap ini adalah sebanyak dua kali volume supernatan yang didapat $(2: 1)$. Selanjutnya pellet (kefiran) yang didapat dibilas dengan air panas, disaring dengan kertas saring, dikeringkan menggunakan oven (Memmert Modell 100-800) pada suhu $80^{\circ} \mathrm{C}$ selama 24 jam dan dihitung beratnya menggunakan metode gravimetri. Proses ekstraksi kefiran mengacu pada penelitian Rimada dan Abraham (2003), Razack dkk. (2013), dan Sajna dkk. (2013) dengan modifikasi.

\section{Analisa Statistik}

Penelitian ini menggunakan Rancangan Acak Lengkap (RAL) dengan variasi perlakuan konsentrasi laktosa pada whey dan variasi komposisi sumber nitrogen. Masing-masing dilakukan 2 kali ulangan sampel. Untuk mengetahui pengaruh masing-masing variasi perlakuan, data hasil penelitian dianalisis menggunakan analisis variansi One Way Analysis of Variance (ANOVA), jika terdapat pengaruh nyata diantara perlakuan, dilanjutkan dengan uji beda nyata Duncan Multiple Range Test (DMRT) pada tingkat signifikasi $\alpha=0,05$.

\section{HASIL DAN PEMBAHASAN}

\section{Biomassa Biji Kefir}

Hasil penelitian menunjukkan bahwa variasi konsentrasi laktosa pada whey tidak berpengaruh nyata terhadap biomassa biji kefir. Namun terjadi kecenderungan penggunaan medium whey dengan konsentrasi laktosa 2,4\% (LW2,4\%) menghasilkan biomassa biji kefir yang lebih tinggi daripada penggunaan medium whey dengan konsentrasi laktosa 1,2\% dan 3,6\% (Tabel 1). Cheirsilp dkk. (2001) menyatakan bahwa konsentrasi laktosa dari whey lebih dari 2\% dapat menghambat pertumbuhan biomassa biji kefir menggunakan kultur Lactobacillus kefiranofaciens JCM. Biomassa biji 
kefir optimum didapatkan pada penggunaan konsentrasi $2 \%$ sumber karbon molasse dan rice bran, serta mengalami penurunan saat digunakan konsentrasi sumber karbon yang lebih tinggi (Razack, 2013). Kuntiya (2010) juga melaporkan bahwa penggunaan sumber karbon air kelapa lebih dari 2\% pada produksi eksopolisakarida dari bakteri Lactobacillus confusus TISTR 1498 menyebabkan turunnya biomassa. Hal ini disebabkan oleh tingginya tekanan osmotik pada jaringan sel yang menyebabkan plasmolisis sehingga mengakibatkan kematian sel mikrobia.

Variasi komposisi sumber nitrogen juga tidak berpengaruh terhadap biomassa biji kefir. Namun secara umum, didapatkan nilai tertinggi biomassa pada sampel LW2,4\%-YE2\%U2\% yaitu sebesar 27,15 g, dan nilai terendah biomassa terdapat pada sampel LW1,2\%-YE4\% dengan nilai sebesar 21,30 g. Sampel perlakuan LW2,4\%YE2\%U2\% menggunakan variasi komposisi sumber nitrogen berupa $2 \%$ yeast extract dan $2 \%$ urea. Hal ini dimungkinkan karena dengan penambahan sumber organik yang dikombinasikan pada konsentrasi tersebut menyebabkan metabolisme mikroorganisme berjalan efektif sehingga biomassa yang dihasilkan tinggi. Kombinasi proporsi sumber nitrogen organik memberikan efek yang lebih baik daripada penambahan sumber nitrogen secara individu atau terpisah.

Menurut Shuler dan Kargi (1992), penambahan sumber nitrogen organik menghasilkan pertumbuhan biomassa lebih cepat dibandingkan nitrogen anorganik karena sintesis asam amino dari sumber nitrogen organik lebih mudah dilakukan oleh mikroorganisme daripada asam amino dari sumber nitrogen anorganik. Pada penelitian Bafrncová dkk. (1999) dijelaskan adanya peningkatan jumlah biomassa setelah penambahan yeast extract pada media fermentasi. Hal ini dikarenakan penambahan yeast extract ke dalam media fermentasi meningkatkan nitrogen alfa amino bebas (free alpha amino nitrogen/FAN) yang merupakan salah satu nutrisi yang diperlukan pada proses biosintesis.

Pada penelitian ini penambahan sumber nitrogen urea secara keseluruhan menghasilkan biomassa yang lebih rendah dibandingkan dengan yeast extract sebagai sumber nitrogen tunggal maupun yang dikombinasikan. Ismael dkk. (2011) menyatakan bahwa hal ini juga terjadi pada penggunaan media susu skim dengan menginokulasikan biji kefir sebanyak $5 \mathrm{~g}$ dan waktu inkubasi selama 120 jam. Bahwa pertumbuhan biomassa terendah didapatkan pada sampel dengan penambahan urea sebagai sumber nitrogen tunggal. Hasil biomassa yang dihasilkan sebesar 0,56 g, lebih rendah dibandingkan dengan hasil biomassa dengan penambahan yeast extract yaitu sebesar 1,02 g.

Hasil penelitian ini juga menunjukkan bahwa setelah fermentasi 24 jam tidak seluruh sampel mengalami kenaikan berat biomassa. Dari jumlah biomassa awal $25 \mathrm{~g}$, sejumlah
Tabel 1. Biomassa biji kefir (g) setelah fermentasi 24 jam

\begin{tabular}{|c|c|c|c|c|c|}
\hline Perlakuan & YE4\% & YE2\%U2\% & $\mathrm{U} 4 \%$ & YE $2 \%$ ET $2 \%$ & ET4\% \\
\hline LW1,2\% & $21,30^{\mathrm{A}}$ & $22,20^{\mathrm{AB}}{ }_{\mathrm{a}}$ & $26,50^{\mathrm{B}}$ & $26,50^{\mathrm{B}}$ & $25,75^{\mathrm{AB}}$ \\
\hline LW2,4\% & $26,85^{\mathrm{A}}{ }_{\mathrm{a}}$ & $27,15^{\mathrm{A}}{ }_{\mathrm{a}}$ & $26,65^{\mathrm{A}}{ }_{\mathrm{a}}$ & $25,40^{\mathrm{A}}{ }_{\mathrm{a}}$ & $22,00^{\mathrm{A}}$ \\
\hline LW3,6\% & $24,95^{\mathrm{A}}{ }_{\mathrm{a}}$ & $24,55^{\mathrm{A}}$ & $24,15^{\mathrm{A}}{ }_{\mathrm{a}}$ & $24,35^{\mathrm{A}}{ }_{\mathrm{a}}$ & $27,05_{\mathrm{a}}^{\mathrm{A}}$ \\
\hline
\end{tabular}

sampel menunjukkan penurunan biomassa menjadi 21,3024,95 g. Penurunan jumlah biomassa juga dilaporkan oleh Ismael dkk. (2011) yang menyatakan bahwa dengan penambahan biji kefir sebanyak $5 \mathrm{~g}$ dalam $100 \mathrm{~mL}$ media, pada akhir fermentasi dihasilkan biomassa yang hasilnya menurun, yaitu sebesar $1,35 \mathrm{~g}$ pada media susu skim dan 1,21 g pada media whey. Menurut Rimada dan Abraham (2003), penurunan berat biomassa biji kefir disebabkan oleh pelepasan jumlah total polisakarida termasuk eksopolisakarida (EPS) terlarut dari biji kefir.

\section{Kadar Etanol}

Alkohol yang dihasilkan selama fermentasi oleh biji kefir berkisar antara $0,11-0,31 \%$ (Tabel 2). Hasil ini lebih rendah dibandingkan dengan kadar etanol dari susu kefir yang berkisar antara 0,5-2,5\% dengan waktu inkubasi selama 24 jam (Rahman dkk., 1992). Harta dkk. (2004) juga melaporkan bahwa proses fermentasi $5 \mathrm{~g}$ biji kefir dalam 1 $\mathrm{L}$ media yang mengandung $40 \mathrm{~g}$ laktosa dapat menghasilkan alkohol $0,5 \%$. Sedangkan apabila dibandingkan dengan biji kefir yang difermentasi dalam susu murni, kadar alkohol yang dihasilkan adalah $0,5 \%-1,0 \%$ (Surono, 2004). Hal ini diduga karena perbedaan kadar laktosa pada medium fermentasi. Rahman (1989) menyatakan bahwa semakin banyak gula yang terkandung dalam media fermentasi, semakin banyak pula alkohol yang dapat diproduksi oleh mikroorganisme akibat perombakan gula menjadi alkohol. Namun, pada penelitian ini sampel LW2,4\% menghasilkan kadar alkohol yang tidak signifikan lebih tinggi dibandingkan dengan sampel LW1,2\%, dan LW3,6\% dengan perlakuan variasi komposisi sumber nitrogen kecuali pada penambahan ekstrak tauge kacang hijau 4\% (ET4\%). Hal ini terjadi karena menurut Bafrncová dkk. (1999), kadar gula tinggi dalam media fermentasi menyebabkan peningkatan tekanan osmosis yang mengganggu viabilitas sel yeast sehingga menyebabkan menurunnya kadar etanol yang dihasilkan.

Penambahan sumber nitrogen yeast extract $4 \%$ (YE4\%) menghasilkan kadar etanol yang tinggi pada sampel LW2,4\% dan LW3,6\%. Kadar etanol tertinggi terdapat pada sampel LW2,4\%-YE4\% sebesar $0,31 \%$ yang tidak berbeda nyata dengan sampel LW3,6\%-YE4\% sebesar 0,25\%. Meskipun demikian penambahan sumber nitrogen yeast extract $4 \%$ tidak 
Tabel 2. Kadar etanol (\%) setelah fermentasi 24 jam

\begin{tabular}{|c|c|c|c|c|c|}
\hline Perlakuan & YE4\% & YE2\%U2\% & $\mathrm{U} 4 \%$ & YE2\%ET2\% & ET4\% \\
\hline LW1,2\% & $0,11^{\mathrm{A}}{ }_{\mathrm{a}}$ & $0,11_{\mathrm{a}}^{\mathrm{A}}$ & $0,23^{\mathrm{AB}}{ }_{\mathrm{a}}$ & $0,29^{\mathrm{B}}$ & $0,21^{\mathrm{AB}}$ \\
\hline LW2,4\% & $0,31^{\mathrm{B}}{ }_{\mathrm{b}}$ & $0,30^{\mathrm{B}}{ }_{\mathrm{b}}$ & $0,28^{\mathrm{B}}{ }_{\mathrm{a}}$ & $0,29^{\mathrm{B}}{ }_{\mathrm{a}}$ & $0,13^{\mathrm{A}}{ }_{\mathrm{a}}$ \\
\hline LW3,6\% & $0,25^{\mathrm{A}}{ }_{\mathrm{ab}}$ & $0,24^{\mathrm{A}}{ }_{\mathrm{b}}$ & $0,24^{\mathrm{A}}{ }_{\mathrm{a}}$ & $0,21^{\mathrm{A}}{ }_{\mathrm{a}}$ & $0,24^{\mathrm{A}}{ }_{\mathrm{b}}$ \\
\hline
\end{tabular}

Keterangan: Notasi huruf kecil $\left({ }_{\mathrm{a}}\right)$ yang sama pada kolom yang sama tiap sampel uji dan notasi huruf besar $\left({ }^{A}\right)$ yang sama pada baris yang sama menunjukkan hasil yang tidak berbeda nyata pada taraf signifikansi $(\alpha=0,05)$.

memberikan efek yang sama pada sampel LW1,2\%YE4\% karena memiliki kadar etanol terendah dengan nilai sebesar $0,11 \%$. Penambahan yeast extract sebagai sumber nitrogen memberikan pengaruh terhadap kadar etanol. Hal ini dimungkinkan karena yeast extract dapat menjadi nutrisi yang baik bagi pertumbuhan yeast dalam biji kefir sehingga metabolisme pemecahan glukosa menjadi etanol lebih efektif dan kadar etanol yang dihasilkan lebih tinggi. Parrondo dkk. (2009) menyatakan bahwa yeast extract merupakan senyawa kompleks yang substansinya berasal dari khamir yang telah mati yang mengandung unsur pokok yang dibutuhkan oleh sel khamir untuk bermetabolisme. Fermentasi biji kefir pada medium yang mengandung laktosa $40 \mathrm{~g} / \mathrm{L}$ dan yeast extract $4 \%$ menghasilkan etanol sebesar $0,5 \% \mathrm{v} / \mathrm{v}$ (Harta dkk., 2004).

\section{Kadar Asam Laktat}

Kadar asam laktat pada media whey keju sebelum fermentasi sebesar $0,23 \%$. Setelah dilakukan fermentasi selama 24 jam, kadar asam laktat yang dihasilkan berkisar antara $0,49-1,47 \%$ (Tabel 3). Secara keseluruhan pada tiap sampel perlakuan, tren kadar asam laktat pada sampel LW3,6\% (C) menghasilkan nilai tertinggi, diikuti dengan sampel LW2,4\% dan LW1,2\%. Semakin tinggi konsentrasi laktosa pada whey menyebabkan aktivitas mikroba semakin tinggi dan penguraian laktosa menjadi gula sederhana yang dimetabolisme menjadi asam laktat juga akan semakin tinggi pula. Setioningsih dkk. (2004) menyatakan bahwa, semakin banyak konsentrasi gula dalam media maka total asam laktat setelah fermentasi akan meningkat.

Ditinjau dari variasi komposisi sumber nitrogen secara keseluruhan, kadar asam laktat tertinggi didapatkan pada sampel LW3,6\%-YE4\% dengan nilai sebesar $1,47 \%$,

Tabel 3. Kadar asam laktat (\%) setelah fermentasi 24 jam

\begin{tabular}{|c|c|c|c|c|c|}
\hline Perlakuan & YE4\% & YE2\%U2\% & $\mathrm{U} 4 \%$ & YE2\%ET2\% & ET4\% \\
\hline LW1,2\% & $1,18^{\mathrm{B}}{ }_{\mathrm{a}}$ & $0,90^{\mathrm{AB}}{ }_{\mathrm{a}}$ & $0,49^{\mathrm{A}}{ }_{\mathrm{a}}$ & $0,90^{\mathrm{AB}}{ }_{\mathrm{a}}$ & $0,60^{\mathrm{AB}}{ }_{\mathrm{a}}$ \\
\hline LW2,4\% & $1,43^{\mathrm{B}}{ }_{\mathrm{a}}$ & $1,09^{\mathrm{AB}}{ }_{\mathrm{a}}$ & $0,65^{\mathrm{A}}$ & $1,13_{\mathrm{a}}^{\mathrm{AB}}$ & $0,78^{\mathrm{A}}$ \\
\hline LW3,6\% & $1,47^{\mathrm{C}}$ & $1,25^{\mathrm{B}}{ }_{\mathrm{a}}$ & $0,77^{\mathrm{A}}{ }_{\mathrm{b}}$ & $1,29^{\mathrm{BC}}{ }_{\mathrm{a}}$ & $0,91^{\mathrm{A}}{ }_{\mathrm{c}}$ \\
\hline
\end{tabular}

Keterangan: Notasi huruf kecil ( $)$ yang sama pada kolom yang sama tiap sampel uji dan notasi huruf besar $\left({ }^{A}\right)$ yang sama pada baris yang sama menunjukkan hasil yang tidak berbeda nyata pada taraf signifikansi $(\alpha=0,05)$. sedangkan kadar asam laktat terendah didapatkan pada sampel LW1,2\%-U4\% sebesar 0,49\%. Pada penelitian ini, sampel LW3,6\%-YE4\% dengan penambahan yeast extract sebesar $4 \%$ dapat menghasilkan jumlah asam laktat yang tertinggi. Hal ini dikarenakan yeast extract merupakan sumber nitrogen organik yang memiliki komponen nutrisi yang beragam dan kompleks serta kaya oleh asam-asam amino yang dibutuhkan untuk aktivitas mikroorganisme. Hal ini selaras dengan penelitian Aeslichmann dan von Stockar (1990) yang menjelaskan bahwa yeast extract merupakan bahan yang biasa ditambahkan kedalam media whey untuk menstimulasi produksi asam laktat oleh bakteri asam laktat (BAL). Ismael dkk. (2011) menjelaskan bahwa hasil kadar asam laktat pada sampel dengan penambahan yeast extract memiliki kadar yang lebih tinggi yaitu sebesar 5,10\% daripada dengan penambahan urea dengan nilai sebesar $2,70 \%$.

\section{Nilai pH}

Nilai $\mathrm{pH}$ whey keju awal sebelum fermentasi adalah sebesar 5,3. Setelah dilakukan fermentasi selama 24 jam, nilai $\mathrm{pH}$ pada tiap sampel berkisar antara 3,49-3,94 (Tabel 4). Secara keseluruhan, tren nilai $\mathrm{pH}$ pada sampel LW1,2\% memiliki kecenderungan yang tidak signifikan lebih tinggi dibandingkan dengan sampel LW2,4\% dan LW3,6\%. Hasil tren nilai $\mathrm{pH}$ ini sesuai dengan kadar asam laktat yang didapatkan dimana nilai $\mathrm{pH}$ dan asam laktat berbanding terbalik, semakin tinggi kadar asam laktat menunjukkan nilai $\mathrm{pH}$ yang semakin rendah.

Variasi komposisi sumber nitrogen berpengaruh terhadap $\mathrm{pH}$ sampel. Berdasarkan variasi komposisi sumber nitrogen, urutan nilai $\mathrm{pH}$ tertinggi hingga terendah terjadi pada sampel dengan variasi komposisi sumber nitrogen sebagai berikut: yeast extract $4 \%$ (YE4\%), yeast extract $2 \%$ dan urea $2 \%$ (YE2\%U2\%), yeast extract $2 \%$ dan ekstrak tauge kacang hijau 2\% (YE2\%ET2\%), urea 4\% (U4\%), ekstrak tauge kacang hijau 4\% (ET4\%). Ditinjau dari variasi komposisi sumber nitrogen dengan nilai $\mathrm{pH}$ terendah dan tertinggi tidak selaras dengan hasil kadar asam laktat. Namun Ismael dkk. (2011) menyatakan bahwa nilai $\mathrm{pH}$ sampel dengan penambahan yeast extract lebih rendah $(3,04)$ dibandingkan nilai $\mathrm{pH}$ sampel dengan penambahan urea $(4,32)$ setelah fermentasi 24 jam dengan penggunaan media susu skim yang ditambahkan $5 \mathrm{~g}$ biji kefir.

\section{Produksi Kefiran}

Kefiran yang diisolasi dari media fermentasi yang dihasilkan pada penelitian ini berkisar antara 0,25-0,63 g/L (data tidak ditampilkan). Kefiran yang diisolasi dari biji kefir memiliki nilai yang tampak lebih tinggi dibandingkan dengan kefiran yang diisolasi dari media fermentasi yaitu berkisar antara $0,21-1,25 \mathrm{~g} / \mathrm{L}$ (data tidak ditampilkan). Sedangkan 
total kefiran didapatkan dari hasil penjumlahan antara kefiran yang diisolasi dari media fermentasi dan biji kefir. Hasil total kefiran setelah fermentasi 24 jam pada penelitian ini berkisar antara 0,63-1,76 g/L (Tabel 5).

Tabel 5. Total kefiran (g/L) setelah fermentasi 24 jam

\begin{tabular}{lrrrrr}
\hline Perlakuan & YE4\% & YE2\%U2\% & U4\% & YE2\%ET2\% & ET4\% \\
\hline LW1,2\% & $1,03^{\mathrm{AB}}{ }_{\mathrm{a}}$ & $1,32^{\mathrm{AB}}{ }_{\mathrm{a}}$ & $0,65^{\mathrm{A}}{ }_{\mathrm{a}}$ & $0,87^{\mathrm{AB}}$ & $1,76^{\mathrm{B}}{ }_{\mathrm{a}}$ \\
LW2,4\% & $0,63^{\mathrm{A}}{ }_{\mathrm{a}}$ & $1,20^{\mathrm{A}}{ }_{\mathrm{a}}$ & $1,46^{\mathrm{A}}{ }_{\mathrm{a}}$ & $1,29^{\mathrm{A}}$ & $1,14^{\mathrm{A}}{ }_{\mathrm{a}}$ \\
LW3,6\% & $1,32^{\mathrm{AB}}{ }_{\mathrm{a}}$ & $1,27^{\mathrm{AB}}{ }_{\mathrm{a}}$ & $0,93^{\mathrm{AB}}{ }_{\mathrm{a}}$ & $1,46^{\mathrm{B}}$ & $0,87^{\mathrm{A}}{ }_{\mathrm{a}}$ \\
\hline
\end{tabular}

Keterangan: Notasi huruf kecil () yang sama pada kolom yang sama tiap sampel uji dan notasi huruf besar $\left({ }^{A}\right)$ yang sama pada baris yang sama menunjukkan hasil yang tidak berbeda nyata pada taraf signifikansi $(\alpha=0,05)$.

Berdasarkan penggunaan variasi konsentrasi laktosa pada whey sebagai media fermentasi secara keseluruhan, didapatkan sampel LW1,2\%- ET4\% menghasilkan rendemen kefiran tertinggi dengan nilai sebesar 1,76 g/L. Sedangkan rendemen kefiran terendah terdapat pada sampel LW2,4\%YE4\% dengan nilai sebesar $0,63 \mathrm{~g} / \mathrm{L}$. Konsentrasi laktosa pada whey sebesar 1,2\% menjadi konsentrasi optimum dalam menghasilkan total kefiran tertinggi. Hal ini dimungkinkan konsentrasi laktosa pada whey sebesar 1,2\% merupakan konsentrasi optimum dalam produksi kefiran. Seperti yang dijelaskan sebelumnya pada penelitian Taniguchi dkk. (2001) bahwa penambahan konsentrasi laktosa yang lebih tinggi tidak meningkatkan kefiran.

Variasi komposisi sumber nitrogen tidak memberikan hasil yang berbeda nyata secara signifikan antar sampel pada hasil total kefiran. Secara keseluruhan, penambahan sumber nitrogen ekstrak tauge kacang hijau 4\% pada konsentrasi laktosa 1,2\% merupakan sampel dengan total kefiran tertinggi. Sedangkan sampel LW2,4\%-YE4\% dengan penambahan sumber nitrogen yeast extract $4 \%$ merupakan sampel dengan nilai total kefiran terendah.

Sumber nitrogen organik dapat menghasilkan eksopolisakarida yang lebih tinggi dibandingkan dengan penggunaan sumber nitrogen anorganik. Oleh karena itu dengan penambahan ekstrak tauge dapat menghasilkan kefiran yang tinggi meskipun sumber karbon yang digunakan tidak sama. Pada penelitian-penelitian sebelumnya disampaikan bahwa rendemen kefiran optimum banyak dijumpai pada sampel dengan penambahan yeast extract (Cheirsilp dan Sirilaor, 2011; Razack dkk., 2013). Namun pada penelitian ini yeast extract tidak dapat menghasilkan rendemen kefiran yang optimum.

Banyak faktor yang dapat mempengaruhi hasil kefiran (eksopolisakarida). Menurut Halim dan Elok (2013), hasil EPS yang dihasilkan dipengaruhi oleh sumber karbon, sumber nitrogen, serta kondisi pertumbuhan bakteri antara lain suhu, pH, dan ketersediaan oksigen. Pham dkk. (2000) menyatakan bahwa pertumbuhan sel pada medium dengan $\mathrm{pH}$ konstan akan menghasilkan yield EPS yang lebih tinggi. Apabila selama fermentasi terjadi proses asidifikasi karena produksi laktat akan mengakibatkan enzim glycohydrolase menjadi aktif pada kisaran $\mathrm{pH} 5$ sehingga yield EPS yang dihasilkan menurun karena proses enzimatis. Sumber karbon yang spesifik dalam medium fermentasi EPS akan menunjukkan hasil yield EPS yang berbeda-beda pada setiap spesies. Ruas-Madiedo dan de los Reyes-Gavilán (2005) menambahkan bahwa kondisi kultur mikroba serta komposisi media fermentasi juga mempengaruhi yield yang dihasilkan dan karakteristik molekulernya.

\section{KESIMPULAN}

Setelah 24 jam fermentasi, jumlah biomassa biji kefir berkisar antara 21,30-27,15 g (berat kering g/250 mL medium fermentasi) dari jumlah biomassa awal $25 \mathrm{~g}$. Cairan fermentasi menunjukkan nilai $\mathrm{pH}$ berkisar antara 3,493,94; kadar alkohol berkisar antara 0,11-0,31\% dan kadar asam laktat berkisar antara 0,49-1,47\%. Total rendemen kefiran yang didapatkan dari ekstraksi biji kefir dan cairan fermentasi berkisar antara 0,63-1,76 g/L. Hasil penelitian ini mengindikasikan bahwa whey keju dengan penambahan sumber nitrogen dapat digunakan sebagai medium fermentasi oleh biji kefir untuk menghasilkan metabolit berupa alkohol, asam laktat dan kefiran. Variasi formulasi media fermentasi yang menghasilkan kefiran dalam jumlah tertinggi adalah penggunaan konsentrasi laktosa whey keju 1,2\% dan sumber nitrogen dari ekstrak tauge kacang hijau sebesar $4 \%$.

\section{UCAPAN TERIMA KASIH}

Terima kasih disampaikan kepada Universitas Sebelas Maret yang telah memberikan dana untuk penelitian ini dengan melalui Hibah Unggulan Fakultas (UF-UNS) dana PNBP tahun 2014 melalui No Kontrak 501/UN27.11/ $\mathrm{PN} / 2014$.

\section{DAFTAR PUSTAKA}

Abraham, A. dan De Antoni, G. (1999). Characteristics of kefir grains gown in milk and in soy milk. Journal of Dairy Research 66: 327-333.

Aeschlimann, A. dan von Stockar, U. (1990). The effect of yeast extract supplementation on the production of lactic acid from whey permeate by Lactobacillus helveticus. Applied Microbiology and Biotechnology 32: 398-402. 
Amanatin, D.R. dan Nurhidayati, T. (2013). Pengaruh kombinasi konsentrasi media ekstrak tauge (met) dengan pupuk urea terhadap kadar protein Spirulina sp. Jurnal Sains dan Seni Pomits 2(2): E182-E185.

Arifiani, N., Sani, T.A. dan Utami, A.S. (2015). Peningkatan kualitas nata de cane dari limbah nira tebu metode Budchips dengan penambahan ekstrak tauge sebagai sumber nitrogen. Bioteknologi 12(2): 29-33.

Association of Official Analytical Chemist (AOAC). (1995). Official Methods of Analysis. 16 ${ }^{\text {th }}$ Edition. Washington DC.

Athanasiadis, I., Boskou, D., Kanellaki, M., Kiosseoglou, V. dan Koutinas, A.A. (2002). Whey liquid waste of the dairy industry as raw material for portable alcohol production by kefir granules. Food Chemistry 50: 7231-7234.

Bafrncová, P., Šmogovičová, D., Sláviková, I., Pátková, J. dan Dömény, Z. (1999). Improvement of very high gravity ethanol fermentation by media supplementation using Saccharomyces cerevisiae. Biotechnology Letters 21: 337-341.

Bottazzi, V., Zacconi, C., Sarra, P.G., Dallavalle, P. dan Parisi, M.G. (1994). Kefir: Microbiology, chemistry and technology. L'industria Del Latte 30: 41-62.

Cheirsilp, B. dan Siliaor, R. (2011). Use of whey lactose from dairy industry for economical kefiran production by Lactobacillus kefiranofaciens in mixed cultures with yeast. New Biotechnology 28(6): 574-580.

Cheirsilp, B., Shimizu, H. dan Shioya, S. (2001). Modelling and optimization of environmental conditions for kefiran production by Lactobacillus kefiranofaciens. Application Microbiology Biotechnology 57: 639-646.

Dewi, E.R.S. (2014). Pertumbuhan kultur probiotik hasil isolat bakteri non patogen dalam berbagai jenis media. Bioma 3(1): 53-65.

Dimitrellou, D., Kourkoutas, Y., Banat, I.M., Marchant, R. dan Koutinas, A.A. (2007). Whey-cheese production using freeze-dried kefir culture as a starter. Journal of Applied Microbiology 103: 1170-1183.

Dimitrellou, D., Kourkoutas, Y., Koutinas, A.A. dan Kanellaki, M. (2009). Thermallydried immobilized kefir on casein as starter culture in dried whey cheese production. Food Microbiology 26: 809-820.

Farnworth, E.R. (2005). Kefir-a Complex Probiotic. Food Research and Development Centre, Agiculture and Agifood Canada, St. Hyacinthe, Quebec, Canada.
Garrote, G., Abraham, A. dan De Antoni, G. (1997). Preservation of kefir grains, a comparative study. Lebensmittel-Wissenchaft Und Technologie 30: 77-84.

Guzel-Seydim, Z.B., Twyffels, J., Seydim, A.C. dan Geene, A.K. (2005). Turkish kefir and kefir grains: microbial enumeration and electron microscobic observation. International Journal of Dairy Technology 58: 25-29.

Halim, C.N. dan Elok Z. (2013). Studi kemampuan probiotik isolat bakteri asam laktat penghasil eksopolisakarida tinggi asal sawi asin (Brassica juncea). Jurnal Pangan dan Agoindustri 1(1): 129-137.

Harta, O., Iconomopoulou, M., Bekatorou, A., Nigam, P., Kontominas, M. dan Koutinas, A.A. (2004). Effect of various carbohydrate substrates on the production of kefir grains for useas a novel baker starter. Food Chemistry 88: 237-242.

Hefdiyah, Arifiyanto, A., Khotim, K., Prio, M.A. dan Kuswitasari, N.D. (2013). Uji potensi medium tumbuh berbahan dasar ekstrak tauge, ekstrak bekatul, dan ekstrak kulit pisang pada kultivasi Spirullina spp. Proceeding Seminar Nasional Biologi X. Surakarta.

Ismael, A.A., Mohamed, F. dan Ayman, K. (2011). Some physicochemical analyses of kefir produced under different fermentation conditions. Journal of Scientific and Industrial Research 70: 365-372.

Katechaki, E., Panas, P., Kourkoutas, Y., Koliopoulos, D. dan Koutinas, A.A. (2009). Thermally-dried free and immobilized kefir cells as starter culture in hardtype cheese production. Bioresource Technology 100: 3618 3624 .

Katechaki, E., Panas, P., Rapti, K., Kandilogiannakis, L. dan Koutinas, A.A. (2008). Production of hard-type cheese using free or immobilized freeze-dried kefir cells as a starter culture. Journal of Agricultural and Food Chemistry 56: 5316-5323.

Kooiman, P. (1968). The chemical structure of kefiran, the water-soluble polysaccharide of kefir grain. Carbohydrate Research 7: 200-211.

Kourkoutas, Y., Kandylis, P., Panas, P., Dooley, J.S.G., Nigam, P. dan Koutinas, A.A. (2006). Evaluation of freeze-dried kefir coculture as starter in feta-type cheese production. Applied and Environmental Microbiology 72: 6124-6135.

Koutinas, A.A, Papapostolou, H., Dimitrellou, D., Kopsahelis, N., Katechaki, E., Bekatorou, A. dan Bosnea, L.A. (2009). Whey valorisation: A complete and novel technology development for dairy industry 
starter culture production. Bioresource Technology 100: 3734-3739.

Koutinas, A.A., Athanasiadis, I., Bekatorou, A., Iconomopoulou, M. dan Blekas, G. (2005). Kefir yeast technology: Scale-up in SCP production using milk whey. Biotechnology and Bioengineering 89: 788-796.

Koutinas, A.A., Athanasiadis, I., Bekatorou, A., Psarianos, C., Kanellaki, M., Agouridis, N. dan Blekas, G. (2007). Kefir-yeast technology: Industrial scale-up of alcoholic fermentation of whey, promoted by raisin extracts, using kefir-yeast granular biomass. Enzyme and Microbial Technology 41: 576-582.

Kuntiya, A., Prasert, H., Charin, T., Ken, S. dan Phisit, S. (2010). Influence of ph, sucrose concentration and agitation speed on exopolysaccharide production by Lactobacillus confusus TISTR 1498 using coconut water as a raw material substitute. Maejo International Journal of Science and Technology 4(02): 318-330.

Magalhães, K.T, Pereira, G.V.M., Dias, D.R. dan Schwan, R.F. (2010). Microbial communities and chemical changes during fermentation of sugary brazilian kefir. World Journal of Microbiology and Biotechnology 33: 1-10.

Obruca, S., Marova, I., Melusova, S. dan Ondruska, V. (2009). Production of polyester-based bioplastics by Bacillus megaterium grown on waste cheese whey substrate under exogenous stress. New Biotechnology 25(Suppl. 1): 257-263.

Otsoa, Lopitz, F., Rementeria, A., Elguezabal, N. dan Garaizar, J. (2006). Kefir: A symbiotic yeast bacteria community with alleged healthy capabilities. Revista Iberoamericana de Micologia 23: 67-74.

Paraskevopoulou, A., Athanasiadis, I., Kanellaki, M., Bekatorou, A., Blekas, G. dan Kiosseoglou, V. (2003). Functional properties of single cell protein produced by kefir microflora. Food Research International 36: 431-438.

Parrondo, J., Garcia, L.A. dan Diaz, M. (2009). Nutrient balance and metabolic analysis in a Kluyveromyces marxianus fermentation with lactose-added whey. Brazilian Journal of Chemical Engineering 26(03): 445-456.

Pham, P.L., Dupont, I., Roy, D., Lapointe, G. dan Cerning, J. (2000). Production of exopolysaccharides by Lactobacillus rhamnosus and analysis of its enzymatic degadation during prolonged fermentation. Applied and Environmental Microbiology 66: 2302-2310.
Plessas, S., Pherson, L., Bekatorou, A., Nigam, P. dan Koutinas, A.A. (2005). Bread making using kefir grains as baker's yeast. Food Chemistry 93: 585-589.

Prihantini, N.B., Damayanti, D. dan Yuniati, R. (2007). Pengaruh konsentrasi medium ekstrak tauge (MET) terhadap pertumbuhan Scenedesmus isolat Subang. Makara Sains 11(1): 1-9.

Rahman, A. (1989). Pengantar Teknologi Fermentasi. Pusat Antar Universitas Pangan dan Gizi. Institut Pertanian Bogor, Bogor.

Rahman, A., Fardiaz, S., Rahayu, W.P., Suliantari, dan Nurwitri, C.C. (1992). Teknologi Fermentasi Susu. Pusat Antar Universitas Pangan dan Gizi. Institut Pertanian Bogor, Bogor.

Razack, A., Vijayagopal, V. dan Viruthagiri, T. (2013). medium optimization for the production of exopolysaccharide by Bacillus subtilis using synthetic source and argo waste. Turkish Journal of Biology 37: 280-288.

Richmond, A. (1986). Handbook of Microalga Culture: Biotechnology and Applied Phycology. CRC Press, New York.

Rimada, P. dan Abraham, A.G. (2006). Kefiran improves rheological properties of glucono lactona induced skim milk gels. International Dairy Journal 16: 33-39.

Rimada, P.S. dan Abraham, A.G. (2001). Polysaccharide Production by kefir grains during whey fermentation. Journal of Dairy Research 68: 653-661.

Rimada, P.S. dan Abraham, A.G. (2003). Comparative study of different methodologies to determine the exopolysaccharide produced by kefir grains in milk and whey. Le Lait 83 (1): 79-87.

Ruas-Madiedo, P. dan de los Reyes-Gavilán, C.G. (2005). Invited review: Methods for the screening, isolation, and characterization of exopolysaccharides produced by lactic acid bacteria. Journal of Dairy Science 88: 843-856.

Sajna, K.V., Sukumaran, R.K., Gottumukkala, L.D., Jayamurthy, H., Dhar, K.S. dan Pandey, A. (2013). Studies on structural and physical characteristics of a novel exopolysaccharide from Pseudozyma sp. NII 08165. International Journal of Biological Macromolecules 59: 84-89.

Setioningsih, E., Setianingsih, R. dan Susilowati, A. (2004). Pembuatan minuman probiotik dari susu kedelai dengan inokulum Lactobacillus casei, Lactobacillus plantarum, dan Lactobacillus acidophilus. Bioteknologi 1(1): 1-6. 
Shiomi, M., Sasaki, K., Murofushi, M. dan Aibara, K. (1982). Antitumor acitivity in mice of orally administered polysaccharide from kefir gain. Japanese Journal of Medical Science and Biology 35: 75-80.

Shuler, M.L. dan Kargi, F. (1992). Bioprocess Engineering Basic Concepts, Prentice-Hall International Inc., New Jersey.

Surono, S. (2004). Probiotik, Susu Fermentasi dan Kesehatan. Yayasan Pengusaha Makanan dan Minuman Seluruh Indonesia (YAPMMI), Jakarta.

Taniguchi, M., Nomura, M., Itaya, T. dan Tanaka, T. (2001). Kefiran production by Lactobacillus kefiranofaciens under the culture conditions established by mimicking the existence and activities of yeast in kefir grains. Food Science and Technology Research 7: 333-337.

Toba, T., Abe, S., Arihara, K. dan Adachi, S. (1986). A medium for the isolation of capsular bacteria from kefir grains. Agricultural and Biology Chemistry 50: 2673-2674.

USDA. (2016). National Nutrient Database for Standard Reference, Release 28 (2016). https://ndb.nal.usda.gov/ ndb/foods/show/2846. [4 April 2016].

Witthuhn, R.C., Schoeman, T. dan Britz, T.J. (2004). Characterisation of the microbial population at different stages of kefir production and kefir grain mass cultivation. International Dairy Journal 15: 383-389. 